\title{
Pompe disease: the role of MRI
}

\author{
C P\&\#233rez Fernández*, L Bosanska, U Plöckinger, A Pöllinger \\ From Proceedings of the 6th European Symposium: Steps Forward in Pompe Disease \\ Berlin, Germany. 23-24 November 2012
}

\section{Introduction}

Glycogen storage disease type II (Pompe disease) is a rare, progressive muscle disorder with a wide range of phenotypic presentations. It is caused by an inherited deficiency of acid $\alpha$-glucosidase (GAA), which leads to lysosomal glycogen accumulation in various tissues, most notably cardiac, skeletal, and smooth muscle. The gradual pathologic storage of GAA in muscle cells causes irreversible muscle damage, with different signs and symptoms, including respiratory insufficiency and muscle weakness. In Pompe disease, defining severity grades is essential for prognosis and for monitoring responses to enzyme replacement therapy (available since 2006). The purpose of this analysis was to describe the MR-imaging findings of patients with Pompe disease being treated in our institution between 2010 and 2012 $(\mathrm{n}=10)$.

\section{Results/discussion}

MR-imaging techniques from skeletal musculature with special fat saturated sequences, together with noninvasive measurement of the urinary glucose tetrasaccharide biomarker, provide an excellent alternative to invasive, often risky, and insufficiently sensitive muscle biopsies. In particular, the T1-weighted turbo spin echo sequences were suitable for depicting muscle atrophy and fibro-fatty muscle degeneration.

\section{Conclusion}

MRI techniques may be appropriately and effectively used to describe muscular changes in patients with Pompe disease.

Published: 29 May 2013

Klinik für Radiologie and Klinik m.S. Hepatologie und Gastroenterologie, Charité Universitätsmedizin Berlin, Berlin, Germany
doi:10.1186/1471-2474-14-S2-P7

Cite this article as: Fernández et al:: Pompe disease: the role of MRI.

BMC Musculoskeletal Disorders 2013 14(Suppl 2):P7.
Submit your next manuscript to BioMed Central and take full advantage of:

- Convenient online submission

- Thorough peer review

- No space constraints or color figure charges

- Immediate publication on acceptance

- Inclusion in PubMed, CAS, Scopus and Google Scholar

- Research which is freely available for redistribution 